\title{
Finance and Development in Italy, 1870-1913
}

\author{
Andrea Incerpi ${ }^{1}$, Barbara Pistoresi ${ }^{2} \&$ Alberto Rinaldi ${ }^{2}$ \\ ${ }^{1}$ Department of Economics, University of Insubria, Varese, Italy \\ ${ }^{2}$ Department of Economics and RECent, University of Modena and Reggio Emilia, Italy \\ Correspondence: Alberto Rinaldi, Department of Economics, University of Modena and Reggio Emilia, Viale \\ Berengario 51, 41100 Modena, Italy. Tel: 39-059-205-6836. E-mail: alberto.rinaldi@unimore.it
}

Received: July 18, 2020

Accepted: August 4, 2020

Online Published: August 25, 2020

doi:10.5539/ijef.v12n9p95

URL: https://doi.org/10.5539/ijef.v12n9p95

\begin{abstract}
This paper analyses the impact of different sources of financing (foreign capital, migrants' remittances, and domestic banks intermediation) on Italy's economic development between 1861 and the World War I. Existing literature has analysed the role of these channels of financial intermediation separately, while this paper for the first time considers them in conjunction. Using IRF from a Cholesky identification structure of a VAR model and relying on an original dataset that combines the most recent series of several financial and economic aggregates, this paper shows that investment in Italy was fuelled by a plurality of sources of funding. A crucial role was played by national saving mobilized by domestic banks and also remittances had a significant impact. Our evidence is instead weaker for foreign capital.
\end{abstract}

Keywords: Italy, finance, investment, impulse response function

\section{Introduction}

The link between finance and economic growth is an evergreen in economics and economic history. Analysed by pioneer studies in the 1950s and 1960s (Gurley \& Shaw, 1955; Cameron, 1967), marginalised in the debate during the following two decades, the study of a causal link between finance and economic growth has been re-launched during the 1990s (King \& Levine, 1993) to became a central issue in macroeconomics (Levine, 1997).

In the field of economic history, this topic has never really disappeared, but the revamp of attention in economics led also to a new spring of historical studies (Rousseau \& Sylla, 2005; Burhop, 2006; Diekmann \& Westermann, 2012; Lehmann-Hasemeyer \& Wahl, 2017). This happened for two main reasons: the nexus finance-growth is an interesting historical topic as such, but also given that financial intermediation might have a clearer and stronger impact on economic growth at earlier rather than later stages of development, for developed economies such link is more likely to be identified using examples from economic history (Rousseau \& Watchel, 1998).

One striking feature of the vast majority of such researches in economic history (as well as in economics) (Note 1) is that they tend to focus either on the role of domestic institutions or on the role of international capital flows (Schularick \& Steger, 2010), with a recent new branch of literature looking at the role of migrant remittances in the process of capital accumulation and growth (Esteves \& Khoudour-Castéras, 2009 and 2011). Maybe surprisingly few (if any) attempts have been made at linking the two and comparing the relative impact of domestic and international channels of financial intermediation. This gap is particularly problematic for the understanding of the process of economic development of those late coming countries which in the decades up to World War I were engaging in a process of industrialisation in the attempt to move from the periphery to the core of the global economy. These countries, on the one hand, have been described as dependent on international capital flows to trigger their cycles of capital formation (Fenoaltea, 2011); on the other hand, however, an earlier literature has stressed the importance of domestic credit channels in either mobilizing domestic saving or, at least, in channelling international funds towards the "right" investment opportunities (Gerschenkron, 1962; Cameron, 1963). In conclusion, the role of international capital flows as compared to national saving and financial intermediation in fostering investment remains to be explored (Jones \& Obstfeld, 2004).

The aim of this paper is to contribute to this literature by looking at the link between international, and domestic, financial intermediation and economic development in Italy in the years between the country's political unification in 1861 and World War I. During these years Italy has been considered by Gerschenkron's (1962) 
seminal work a clear case of banks-driven growth; subsequent researches, however, have criticised his original idea, but rather than dropping overall the view of a finance-driven growth, they put emphasis on channels different from the one originally suggested (i.e. German-style universal banks). Scholars therefore have analysed the role played by different types of domestic institutions (i.e., small local banks), or international capital flows. The relative importance of different channels, however, is still unclear, and even more so is the link between the two; in fact, even the basic relationship between financial deepening and economic growth is still part of a debate (Della Torre et al., 2008).

In particular, this paper analyses the relative weight of domestic vs international sources of finance in funding investment in Italy; whether these channels were interlinked; the contribution of emigrants' remittances; and the types of investment (construction vs other fixed investment, i.e., plant, machinery and industrial equipment) the various sources of finance were addressed to.

This paper uses the newest data available and econometric techniques and it is structured as follows: Section 2 summarises the debate on the role of various sources of financing on Italy's economic development and sets up some hypotheses to be tested; Section 3 presents the sources and data we use in our analysis; Section 4 presents the econometric methodology to test the role of international and domestic financing on the Italian economy (VAR estimation and Impulse Response Analysis); Section 5 presents and discusses the results; finally, Section 6 concludes.

\section{The Debate on Financing Italy's Economic Development}

Studies focussing on banking and financial aspects figure prominently in the economic history of Italy during the period from Unification to World War I. The pioneer of this research strand is Gerschenkron (1962) who provided the first proper narrative of Italian economic development centred around financial factors rather than real ones. In his view, backward economies such as Italy could develop and "catch-up" with more advanced countries only thanks to "substitution factors" able to ignite the potential rapid growth implicit in the state of economic backwardness. In the Italian case, the substitution factor was identified in specific financial institutions, German-style universal banks that were set up in the mid-1890s in the wake of the collapse of the previous French-style credit mobilier-type commercial banks. In Gerschenkron's view, German-style universal banks nurtured the new fast-growing technology- and capital-intensive sectors of the second industrial revolution by supplying them with capital and managerial skills. Hence - Gerschenkron claimed - the phase of fast growth since the turn of the century (Italy's "big spurt" in the jargon of the time) was due to new financial institutions and their operations.

A few decades later, Gerschenkron's analysis was supported by an econometric study (Warglien, 1987). This research showed that commercial banks were the engine of financial support to modern sectors and fluctuations in investment in capital goods depended on variations in commercial bank lending.

The claim that commercial banks (and in particular universal banks) had to be considered as the factor behind the development of the Italian economy up to World War I was criticized by more recent historiography. Criticisms emerged along three main lines: firstly, an erroneous view of the actual functioning of universal banks, leading to overestimate their relevance and impact on the economy; secondly, the parallel underestimation of the role played by other domestic financial institutions; thirdly, the possibility that Italian development was led by international rather than domestic financial flows.

Banking historians such as Confalonieri $(1974-76,1982)$ and Hertner (1984) firstly claimed that Italian universal banks were not the novelty that Gerschenkron had argued. Their view was that domestic financial institutions did matter, in general, for the process of economic development in Italy, but universal banks were hardly different from the banks that existed before them. The credit institutions destroyed by the 1890s crisis, in fact, channelled international (mainly French) financial resources into Italian productive investment in a way similar to what decades later universal banks did with German capital. Logically, the implication of this argument was that if universal banks were not very different from their predecessors, it was very hard to attribute them a much stronger power and influence over the Italian economic development.

This argument was further perfected by Fohlin $(1998,1999)$. This author showed that universal banks tended to fund large and well-established companies instead of promising, but risky, small firms, which needed venture capital. She also claimed that firms linked to the universal banks performed similarly - in terms of growth of financial capital, fixed assets and revenues - to those that were not (Note 2). The general conclusion was that universal banks played a limited role in fostering the investment of Italian firms during a critical phase of industrialization, dismissing Gerschenkron's claim. 
A parallel line of research, still from banking history, further contributed to undermine Gerschenkron's view, by showing the structural contribution to Italian industrial growth provided by local savings institutions and cooperative banks. While Gerschenkron dismissed the role of small local banks and believed in the stereotype that these institutions only or mainly invested in safe public bonds or similarly state-guaranteed securities, scholars such as Carnevali and Conti showed how these banks - that overall collected about half of total Italian savings - became progressively more active in the financing of trade and light industry, especially at local level (Carnevali, 2005; Conti, 2007). Some recent works by Vasta et al. (2017) and Rinaldi and Spadavecchia (2019) have shown, by using network analysis and quantitative methodologies, that large universal banks were not the only relevant actors that supported Italian industrialization; in fact, in several areas of the country (especially Lombardy and some other regions of the North), small local banks had established strong ties with industrial firms already by 1913.

The strongest attack to Gerschenkron's view, however, rather than from banking history, came from macroeconomic studies. In a number of articles, and thanks to original reconstructions of historical series of GDP and industrial output, Fenoaltea challenged the very idea of a "big spurt" in the Italian economy identified by Gerschenkron. According to Fenoaltea $(1988,2003,2011)$, instead, Italy was characterised by a steady process of long-term economic growth with medium-term cyclical fluctuations around the trend due to the cyclical character of the construction industry. Further, and this represents a second structural criticism to Gerschenkron - swings in Italian construction and in industrial investment were driven by exogenous fluctuations in international capital flows triggered by British capital exports, with little (if any) role given to domestic savings. However, this claim was reconsidered by Fenoaltea's (2017) more recent work, that limits swings driven by capital inflows to investment in construction and infrastructure, whereas industrial investment followed a different path and grew quite steadily over the whole half-century after unification.

Finally, Italy was a country of mass-emigration (Gabaccia, 2000; Fauri, 2015) and it figures prominently in studies on the economic role of remittances. Clearly, migrants generated a conspicuous flow of resources able to substantially affect the level of money supply. What is less clear, however, is how this money was channelled into the economy and the impact it had on economic growth.

Overall, the debate analysed above provides a number of (often opposite) claims to be addressed. They can be summarised as follows:

a) Did domestic sources of finance dominate international ones, or did the opposite occur?

b) Were these channels interlinked?

c) What was the contribution of emigrants' remittances?

d) What kind of investment (i.e., plant, machinery and transport equipment vs. construction) were the various sources of finance channelled to?

\section{Sources, Data and Methodology}

The choice of the most suitable variables to measure both the financial and real side of the economy is in itself part of the debate on the finance-development link. In economic history theoretical considerations about which variables to use are also linked to issues of data availability and/or reliability. Before moving to the econometric investigation of the questions described above, it is therefore necessary to introduce the data used in our analysis. Although no original series as such is produced, the paper is based mainly on some original re-combinations of the most up-dated available ones.

\subsection{Financial Aggregates}

\subsubsection{International Financial Flows and Remittances}

International capital flows are the trickiest and most debated variable in terms of which proxy to use to measure them. Traditionally, researches have been based on net capital flows, i.e. the difference between foreign financial resources invested in a given country and what residents of that country invest abroad. Recently, however, a view seems to have emerged claiming that the pattern of gross capital flows often shows a behaviour very different to the one of net capital flows and that, in general, it represents a better proxy to capture the action of international investors (Broner et al., 2013). Despite this preference in economics, things are much more complex in economic history given the issues of data availability. A recent series of gross capital flows into various countries has been provided by Stone (1999), but this only covers British funds, not always an adequate proxy for the whole of international investment. As a result, recent works have used instead an estimate of international capital flows derived from the capital account of the balance of payment (Borio et al., 2014; Jones \& Obstfeld, 2004), or this 
variable alongside Stone's reconstruction (Schularick \& Steger, 2010).

In the case of Italy, the two existing directly-calculated series of international capital flows are both problematic. Italy was traditionally dependent on the French or the German financial market, making Stone's data a particularly poor proxy. The best alternative is a series of net capital flows provided by Incerpi (2018). This series relies on new estimates of the invisible trade balance, from 1861 to 1914, concerning four main invoices: remittances, tourism, freights, interests. Unlike Istat, the methodologies adopted to estimate the new series are explained in detail. Remittances refer to the stock of Italian emigrants abroad and the average value of remittance per emigrant. The methodology varies according to different sources and data available within the period. The series of tourism relies on three points instead: the number of tourists by sea and by train, the average time spent by tourists in Italy, the daily average expenditure per tourist. Contrary to the conventional wisdom, tourism is here the key element balancing the current account (Incerpi, 2019). The estimates on freights exploit data on world trade statistics (Federico \& Tena-Junguito, 2016) together with information on trade routes and commodities in order to calculate inbound and outbound unit freight series. These estimates also include the cost of insurance for both imports and exports commodities. Finally, the estimate of the interests paid abroad or to foreign investors on the Italian public debt and on other private investments completes the invisible trade balance. Incerpi's estimates on net capital flows confirm the long-lasting hypothesis, from Stringher (1912) to Fenoaltea (2011), stating that Italian capital imports have been underestimated by conventional reconstruction.

However, even if it is more accurate than previous studies, Incerpi's series shows that Italy was a net capital exporter in seventeen over forty-four years between 1870 and 1913. This does not make it a good proxy for gross capital inflows that are by definition higher than zero.

Thus, following Fenoaltea (2011) we have eventually decided to use the trade balance to proxy of capital inflows. In particular, we rely on the new series provided by Federico et al. (2011), which massively improved Istat's (1957) old series. Although the new series confirms the expected pattern - i.e., Italy's trade balance showed a structural deficit (apart from 1871) - this was, however, more severe than previously thought, especially during the years of rapid industrialisation at the beginning of the $20^{\text {th }}$ century. Overall, capital inflows show swings in the early 1870s, in the 1880s and from 1906 to 1910 (see Figure 1).

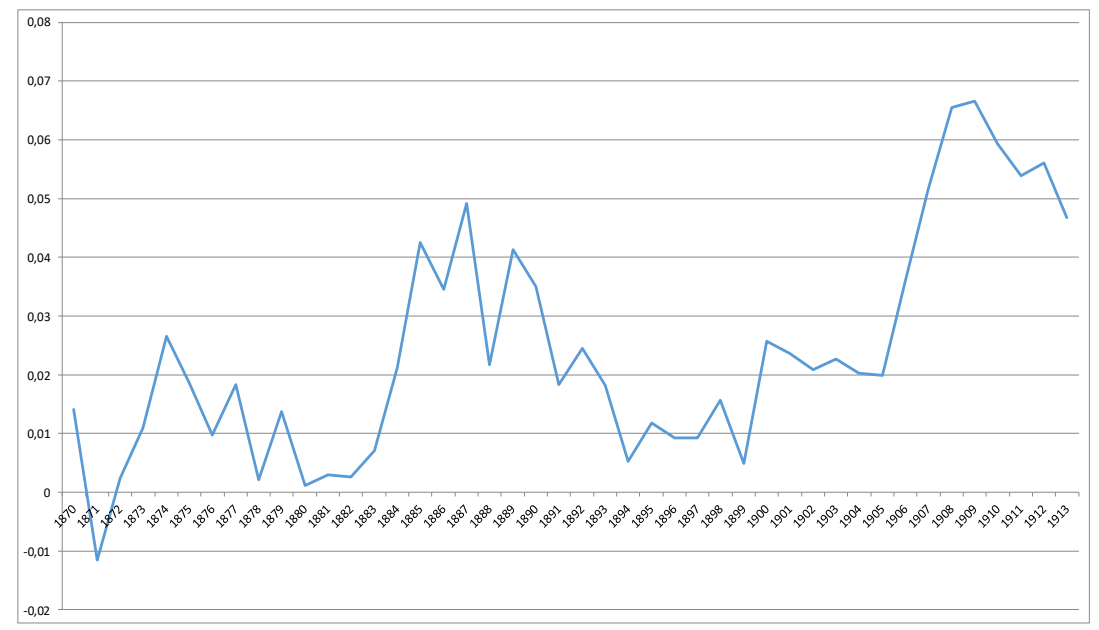

Figure 1. Capital inflows (inverse of the trade balance) as a ratio to GDP (1870-1913)

Much better data are available for remittances. Incerpi's series shows a constant trend until the beginning of 19th century given by a slight increase of the stock of Italians abroad for the first decades after Unification (Incerpi, 2019). The breaking point is given by the set of migration law in 1901. Until then, Italian emigrants could exploit various and risky means: international money orders, consular orders, remittances by private bankers and hand-carried remittances (De Rosa, 2000). The law issued in 1901 entrusted the Bank of Naples to organize the system of remittances substituting the Italian private bankers. This safer process stimulated emigrants in sending their savings, increasing the macroeconomic impact of remittances on national account (see Figure 2). As ratio to GDP, remittances stay below the $1 \%$ by the end of the century, increasing with an average above the $2,5 \%$ between 1903 and 1914 reaching peaks around $4 \%$. 


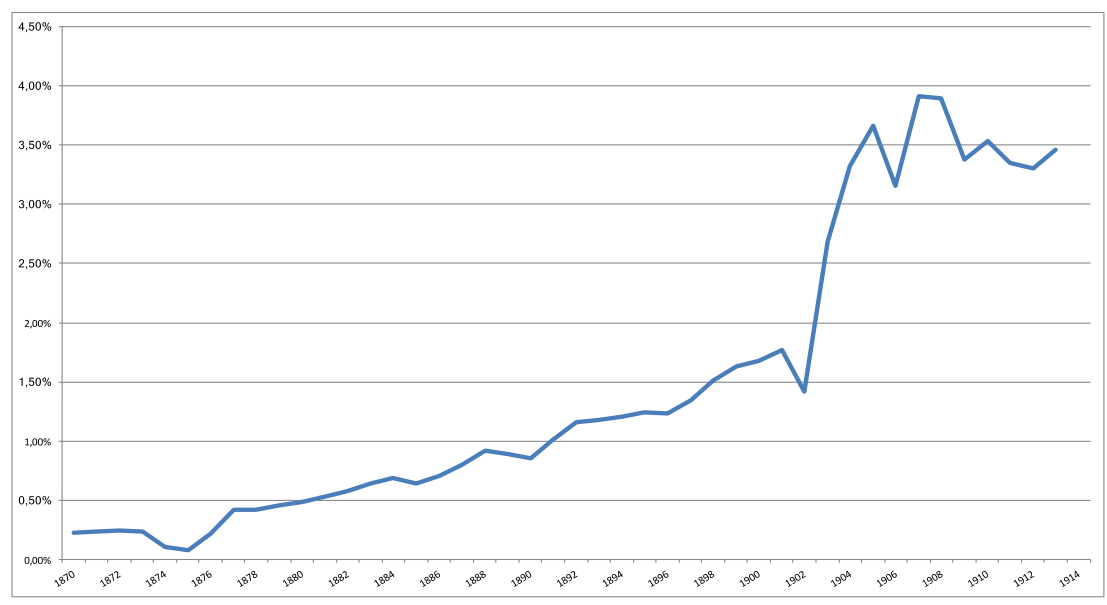

Figure 2. Remittances as a ratio to GDP (1870-1913)

\subsubsection{Domestic Financial Intermediation}

In the recent literature, bank assets (either total or disaggregated by types of bank) have emerged as the standard measure of domestic financial intermediation (Burhop, 2006; Rousseau \& Watchel, 1998), although occasionally scholars have used also/or proxies such as the number of banks (Lehmann-Hasemeyer \& Wahl, 2017; Rousseau \& Sylla, 2005) or banks' total lending (Diekmann \& Westermann, 2012).

In the case of Italy, recent reconstructions are available for total banks assets (De Bonis \& Silvestrini, 2014), but for data disaggregating by type of banks (i.e., commercial banks, savings banks, and cooperative banks) we still have to rely of older data by De Mattia (1967, v. 1, t. 2, Tav. 23) who, however, worked on primary sources very similar to the ones used by the most recent studies. This is the series we use for our analysis. Figure 3 shows that the ratio of commercial bank assets (Note 3) to GDP was always much higher than that of both capital inflows and remittances. Moreover, the dynamics of commercial bank assets is less volatile from one year to another than that of capital inflows. Nonetheless, the ratio of commercial bank assets to GDP also show swings that peak in the early 1870s, in the late 1880s and in 1906, while troughs can be observed in 1877 and in 1896.

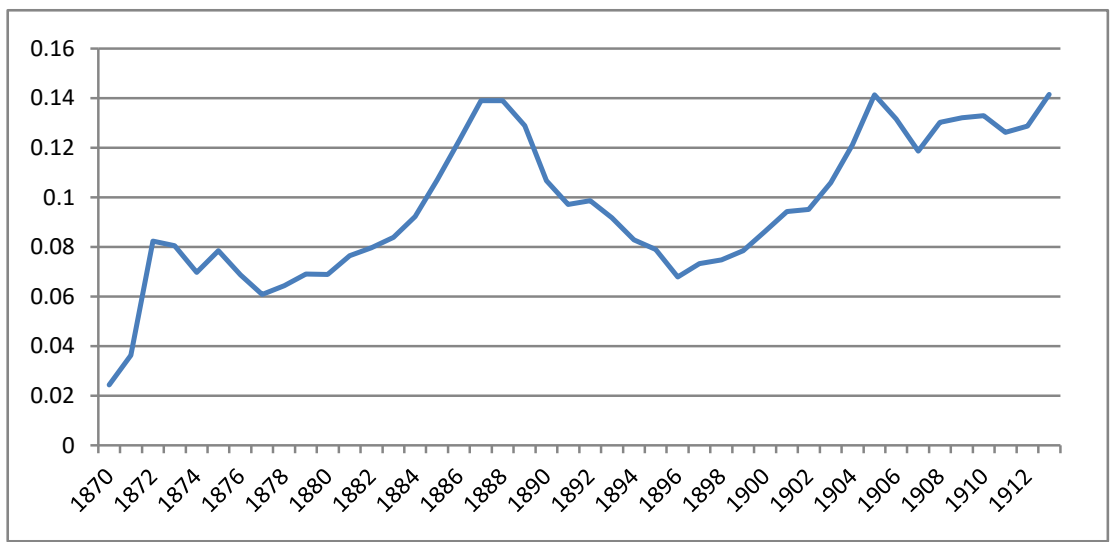

Figure 3. Commercial bank assets as a ratio to GDP (1870-1913)

\subsection{The Real Economy}

To measure the impact of different sources of financial intermediation on the economy, three variables are used in the literature: GDP; aggregated investment, investment disaggregated by type/industry. Disaggregated investment has been used to test a model of the economy assuming the existence of two sectors relying, to different extents, on domestic or international credit (Diekmann \& Westermann, 2012).

In this case the construction of the series is less problematic than for financial measures, as recent and very reliable reconstructions exist for most variables. Among various alternatives, we decided to use the most recent series provided by Italy's central bank (Baffigi, 2017), for GDP, total investment, and investment disaggregated between construction, and other fixed investment. These data have been criticized by Fenoaltea (2018), 
according to whom they are grossly distorted by the use of the old Vitali/Istat deflators to convert constant-price series into current-price series (and vice versa) that in his view are very poor. However, Fenoaltea provides only constant-price series, whereas our financial series must be used with current-price series. Thus, we have eventually decided to use Baffigi's series as the alternative would have been to renounce to current-price data altogether. In fact, it must be considered that Baffigi used the Vitali/Istat deflators to interpolate the full current-price accounts for the benchmark years $(1891,1911,1938,1951)$ that were reconstructed by a research team established by the Bank of Italy (Rey 1992, 2000, 2002) to which he added a new benchmark for 1871 (Baffigi, 2011). As these benchmarks are in current prices, Baffigi divided them by the constant-price accounts provided by Fenoaltea and in this way he obtained his deflators for the benchmark years. Such a procedure should limit the distortion (Note 4).

More generally, we must keep in mind that historical accounts are only approximate reconstructions - and in many cases interpretations - drawn from a variety of sources (both primary and secondary) that cannot be considered as the national accounts produced by modern statistical institutes. As a result, historical national accounts for the pre-statistical age are always debatable hypotheses. Thus, we think it is hard to dismiss a series altogether especially if, as it is in our case, no alternative has been provided for Italy's historical accounts in current prices.

Figure 4 shows total investment, investment in construction and other fixed investment as a ratio to GDP. The dynamics of total investment reflects principally that other fixed investment - e.g., industrial investment - with the exception of the swing in the 1880 s that seems led by investment in constructions.

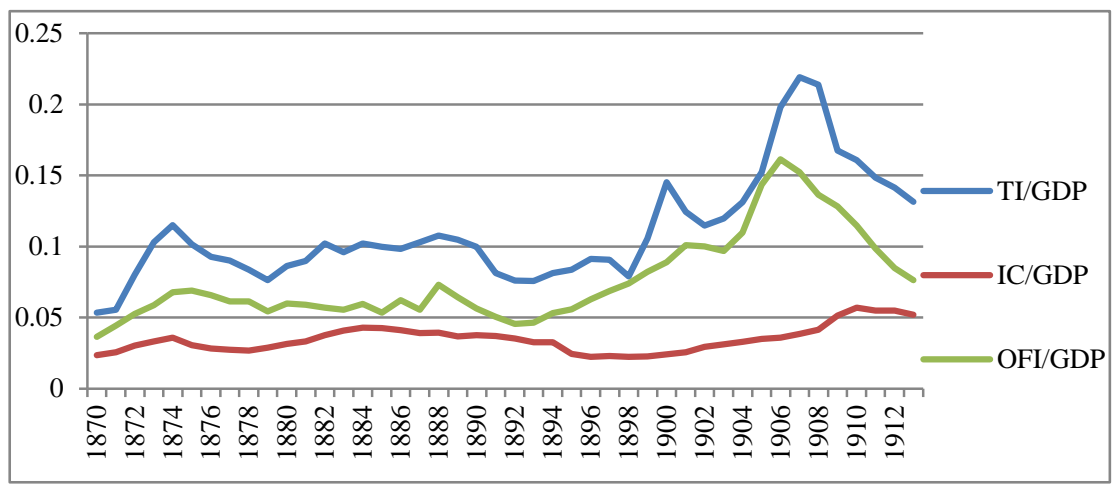

Figure 4. Investment as a ratio to GDP (1870-1913)

Note. Legend: $\mathrm{TI}=$ Total investment; $\mathrm{IC}=$ Investment in constructions; $\mathrm{OFI}=$ Other fixed investment.

\section{Econometric Methodology}

In this section we show the econometric model used to investigate the impact of different sources of international and domestic financing on Italy's economic development. We start considering a vector autoregression model (VAR) that describes the evolution of a set of variables of interest, over the same sample period $(t=1, \ldots, T)$ as a linear function of only their past values (Note 5). A p-th order VAR, denoted $\operatorname{VAR}(\boldsymbol{p}$ ), is:

$$
\boldsymbol{Y}_{\boldsymbol{t}}=\boldsymbol{c}+\phi(\boldsymbol{L}) \boldsymbol{Y}_{\boldsymbol{t}-1}++\varepsilon_{\boldsymbol{t}}=\boldsymbol{c}+\phi_{1} \boldsymbol{Y}_{\boldsymbol{t}-1}+\ldots+\phi_{\boldsymbol{p}} \boldsymbol{Y}_{\boldsymbol{t}-\boldsymbol{p}}+\varepsilon_{\boldsymbol{t}}
$$

where $Y$ in our case is a vector of three variables: $\boldsymbol{Y}_{\boldsymbol{t}}=\left(\boldsymbol{y}_{1, t}, \boldsymbol{y}_{2, t}, \boldsymbol{y}_{3, t}\right), \boldsymbol{E}\left(\varepsilon_{\boldsymbol{t}}\right)=0, \boldsymbol{E}\left(\varepsilon^{2}{ }_{i, t}\right)=\sigma^{2}{ }_{i}, \mathrm{i}=1 \ldots \mathrm{n}$; in general $\boldsymbol{E}\left(\varepsilon_{i t}, \varepsilon_{j t}\right) \neq 0$ for $\boldsymbol{i} \neq \boldsymbol{j}$. The VAR expresses each variable as a linear function of its own past values, the past values of all other variables being considered and a serially uncorrelated error term. Thus in our case the VAR involves three equations where for example current capital inflows are a function of past values of the same variable, of bank assets and investment. Current bank assets and current investment are expressed in similar way in their respective equations. Each equation is estimated by OLS. Information criteria are used to choose the maximum lag $p$ in the VAR model. To estimate a VAR all variables have to be of the same order of integration. The following cases are distinct:

- All the variables are I(0) (stationary) and a VAR in levels should be estimated;

- All the variables are $\mathrm{I}(1)$ (non-stationary). This implies the following cases:

- The variables are cointegrated: it is possible estimate a VAR in levels (Note 6) or equivalently a Vector error correction model (VECM) in which an error correction term (e.g. the long-run equilibrium among 
the variables) is included.

○ The variables are not cointegrated and they have first to be first differenced. In this case a VAR in first differences should be estimated.

From an economic point of view, if the joint dynamics of a set of variables can be represented by a VAR model, then the structural form is a depiction of the underlying, "structural", economic relationships. Now we introduce the Structural VAR definition and we explain the relationship between reduced form and structural form. A structural VAR with p lags (sometimes abbreviated SVAR) is:

$$
A_{0} Y_{t}=c+A(L)_{1} Y_{t-1}+u_{t}
$$

The matrix $A_{0}$ identifies contemporary structural relationships among the variables, that is suggested by an

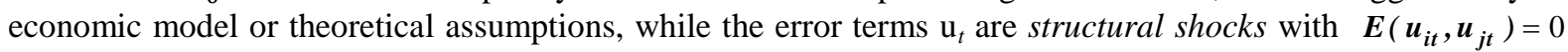
for $i \neq j$. The relation between the reduced and structural form disturbances is as follows:

$$
\varepsilon_{t}=\boldsymbol{A}_{0}^{-1} \boldsymbol{u}_{\boldsymbol{t}}
$$

It is possible to derive the dynamic response of a specific variable in the system to a specific structural shock over a time period (impulse response function) imposing the simple identification scheme given by:

$$
\boldsymbol{A}_{0}{ }^{-1}=\left(\begin{array}{ccc}
1 & 0 & 0 \\
\boldsymbol{a}_{21} & 1 & 0 \\
\boldsymbol{a}_{31} & \boldsymbol{a}_{32} & 1
\end{array}\right)
$$

It is known as Cholesky causal chain (or Cholesky decomposition) and implies that all the structural parameters are identified and hence the related IRF. On this basis in a three variables system we have the following links between the estimated shocks $\varepsilon$ and the structural shocks $u$ :

$$
\begin{aligned}
& \varepsilon_{1}=\boldsymbol{u}_{1} \\
& \varepsilon_{2}=\boldsymbol{a}_{21} \boldsymbol{u}_{1}+\boldsymbol{u}_{2} \\
& \varepsilon_{3}=\boldsymbol{a}_{31} \boldsymbol{u}_{1}+\boldsymbol{a}_{32} \boldsymbol{u}_{2}+\boldsymbol{u}_{3}
\end{aligned}
$$

This identification scheme incorporates the following assumptions concerning the variables of interest: the capital inflows shock $\left(u_{1}\right)$ is contemporary exogenous to bank assets and investment; the bank assets shocks $\left(u_{2}\right)$ is contemporary exogenous to investment.

The dichotomy of the literature on financial intermediation and economic performance, i.e. the fact that domestic and international sources of financing are usually analysed separately, deprives us from a theoretical model establishing in a clear and robust way causal links between international financial flows, domestic credit intermediation, and investment. If it is plausible that foreign capital inflows and remittances are exogenous to domestic bank assets and investment, the relationship between the latter two variables is more uncertain. Bank assets might be endogenous to investment (and vice versa), however the causality restriction on the contemporaneous links among the variables reduce the potential problem of endogeneity on all the other frequencies. Nonetheless, the nexus between bank assets and investment was analysed by using Granger causality test that suggests unilateral causation from commercial bank assets to total investment (Note 7).

\section{Empirical Results}

In this section we report the estimated impulse response functions (IRF) from a three variables VAR with one or two lags, depending on the exercises, as suggested by BIC information criterion (Note 8). The VAR specification is in levels because all the variables included are I(1) and cointegrated (see Table A1 and A2 in the Appendix). The IRF are identified by Cholesky scheme as in Eq. (3). All series are in current prices (million euros) as a ratio to GDP. All ratios are in logs. Specifically, the variables used are the following:

Financial variables:

Foreign Capital inflows: trade balance / GDP;

Remittances: remittances / GDP;

Bank assets (commercial banks): Total assets of commercial banks / GDP;

$\underline{\text { Real variables: }}$

Investment (total): total investment / GDP;

Investment (construction): investment in constructions / GDP;

Other fixed investment (ofi): other fixed investment (other than in construction) / GDP; 
To address the set of questions highlighted in Section 2, we provide a number of econometric exercises exploring such issues as whether domestic sources of finance dominate international, or the opposite occurred; whether domestic banks helped channelling foreign capital to investment, or international investment took place via alternative channels; the role of emigrants' remittances in funding investment in Italy; finally, whether domestic and international sources of funding went towards different types of investment, i.e., constructions vs. other fixed investment.

\section{Exercise 1: Foreign capital, domestic banks, and total investment}

The first exercise provides a general analysis of two basic aspects: the importance of foreign capital relative to national saving as a source of the funding of total investment in Italy, and the role of domestic banks in channelling international capital inflows.

Figure 5 reports the IRFs from a VAR containing capital inflows, total bank assets (for commercial banks) and total investment. The results are as follows:

a. Foreign capital inflows have no significant impact on the assets of commercial banks (plot 1).

b. However, foreign capital has a positive direct impact (i.e., without being channelled by domestic banks) on total investment starting from the second year (plot 2).

c. Total assets of commercial banks have a positive impact on total investment significant on all frequencies (plot 3).

Overall, these results emphasize above all the fundamental role of national saving's mobilization and domestic banks in supporting the economic development of Italy up to WWI. However, they indicate that also other factors were at work, in particular foreign capital, at least in the medium and long run. At the same time, we find no evidence that foreign capital and domestic banks operated in an integrated market and did not represent two parallel channels. It cannot be rule out that foreign capital was channelled not by Italian commercial banks in general, but by a sub-set of them, e.g., the larger German-style universal banks established in the mid-1890s. However, the limited number of observations prevents us to test this hypothesis.

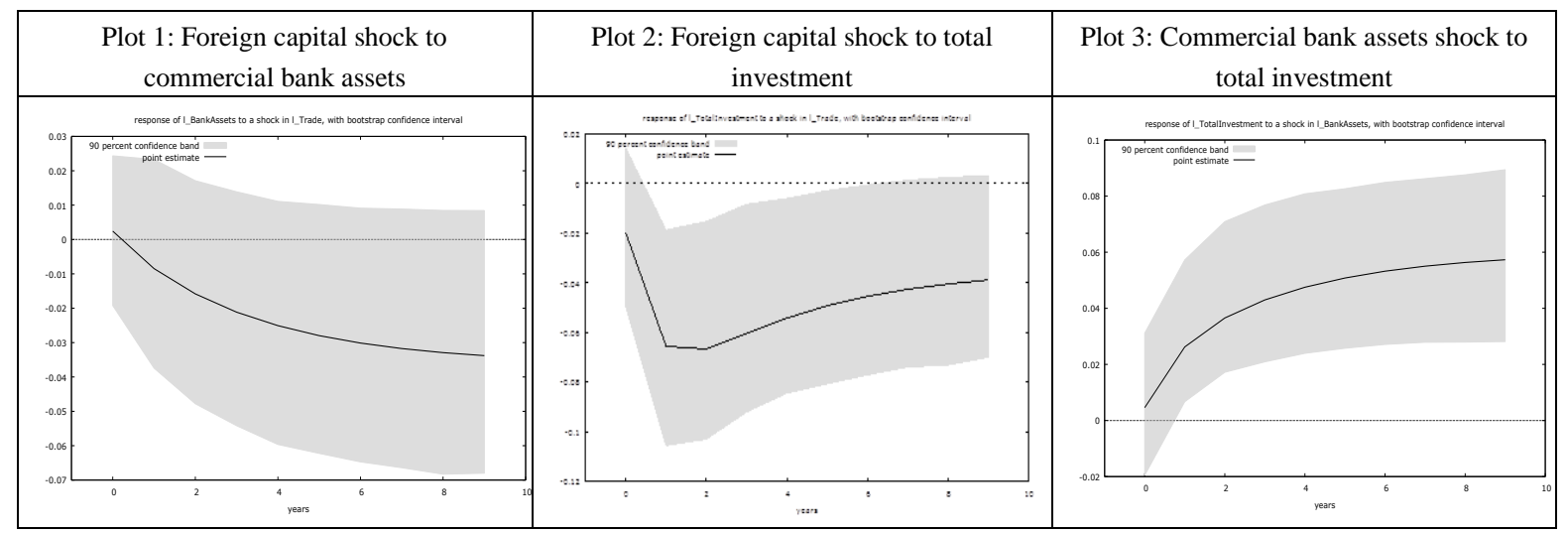

Figure 5. IRFs in the foreign capital inflows, commercial bank assets, total investment VAR

Note. The solid lines trace the impulse responses while the area between the two dotted lines the $90 \%$ bootstrap confidence bands. These IRF are from VAR (1). The VAR lag length is selected by BIC.

\section{Exercise 2: Remittances, domestic banks, and total investment}

Results of previous exercises show that capital sent by foreign investors affected total investment in Italy; a question that remains open, however, is what was the role of remittances from Italian emigrants abroad. To address this point, we repeat Exercise 1 substituting foreign capital with remittances. The results are the following (see Figure 6):

a. Remittances significantly affect commercial banks' assets on all frequencies (plot 1). This was probably a result of the monopoly assigned to the Banco di Napoli in 1901 to transfer remittances from emigrants' destination countries to Italy.

b. There is a positive direct effect of remittances on total investment also significant on all frequencies (plot 2). This plot is very similar to plot 1 which can signify that most remittances passed through the banking system. 
c. Commercial bank assets have a positive permanent impact on investment in the medium long run at the limit of the $90 \%$ bootstrap confidence band (plot 3).

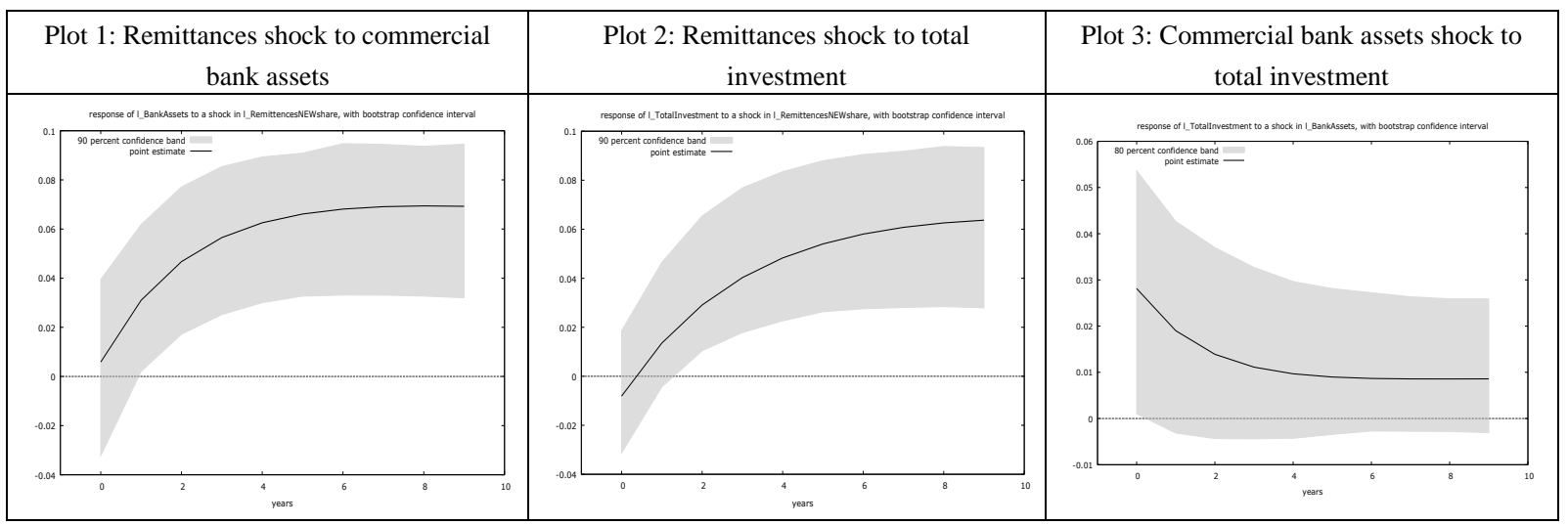

Figure 6. IRFs in the remittances, commercial banks assets, total investment VAR

Note. The solid lines trace the impulse responses while the area between the two dotted lines the $90 \%$ bootstrap confidence bands. These IRF are from VAR (1). The VAR lag length is selected by BIC

This Exercise helps to shed light on the way in which remittances were channelled into the Italian economy and the impact they had on economic development. The most important effect of remittances stressed in the literature was to allow the adjustment of the CA balance thereby enabling the country to import the capital goods, technology, and raw materials needed for industrialization (Balletta, 1976; Fauri, 2015). Remittances also allowed a large inflow of savings in the postal coffers, making loans to local authorities possible, while substantial part of them were used for the purchase of Treasury bonds (Coletti, 1911). More recent literature (Esteves \& Khoudour-Castéras, 2009 and 2011) highlighted the role of remittances in prompting the nation's financial development and the diffusion financial services, even in the most remote areas.

Another strand of literature focuses instead on the microeconomic effects of remittances, and stresses that they were used for the purchase or renovation of houses and for the purchase of land, as well as for settling debts for the family (De Clementi, 1994; Sori, 1987; Coletti, 1911; De Rosa, 2011). Moreover, remittances were used by Italian families to increase their consumption and encourage their children's school attendance (Faina, 1911). Finally, some scholars highlight the micro-entrepreneurial initiatives triggered by the investment in Italy of resources deriving from remittances by the emigrants themselves, once they have been repatriated, or by their relatives in Italy (Coletti, 1911); direct proposals from local credit institutions for profitable productive investment projects, or alternatively, to expand the offer of credit at lower rates than those of the usurers, which were followed by the birth of new commercial and industrial activities (Douki, 2001; Ferrandino, 2011). Overall, the result of this Exercise bring new evidence in support of this latter claim, i.e., that remittances were used to a significant extent to boost investment.

\section{Exercise 3: Foreign capital, remittances, domestic banks, and sectoral investment}

Having established a role of both foreign and domestic capital on total investment, a further step in our investigation consists in analysing what kind of investment finance was directed to. Specifically, the goal is to capture whether foreign capital financed investment in plant and machinery in industry - e.g., "other fixed investment" in Baffigi's taxonomy - or, rather, investment in construction. We therefore repeat Exercise 1 disaggregating by type of investment. The findings of this new Exercise are shown in Figures 7 and 8:

a. Foreign capital does not impact either directly or indirectly on industrial investment (Figure 7, plots 1 and 2).

b. Similarly, foreign capital has no direct and indirect effect on investment in construction too (Figure 8, plots 1 and 2)

c. Conversely, commercial bank assets have always a positive effect on all types of investment, both industrial and in construction, in all frequencies (Figure 7, plot 3 and Figure 8, plot 3). 


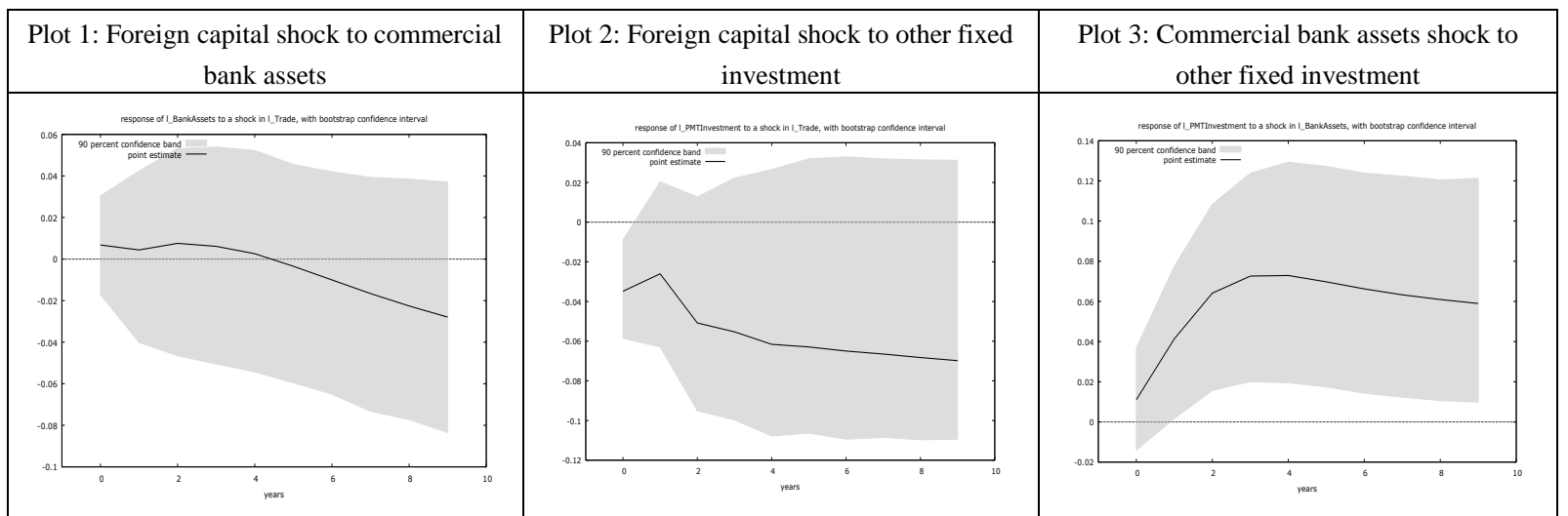

Figure 7. IRFs in the foreign capital inflows, commercial bank assets, industrial investment VAR

Note. The solid lines trace the impulse responses while the area between the two dotted lines the $90 \%$ bootstrap confidence bands. These IRF are from VAR (2). The VAR lag length is selected by BIC.

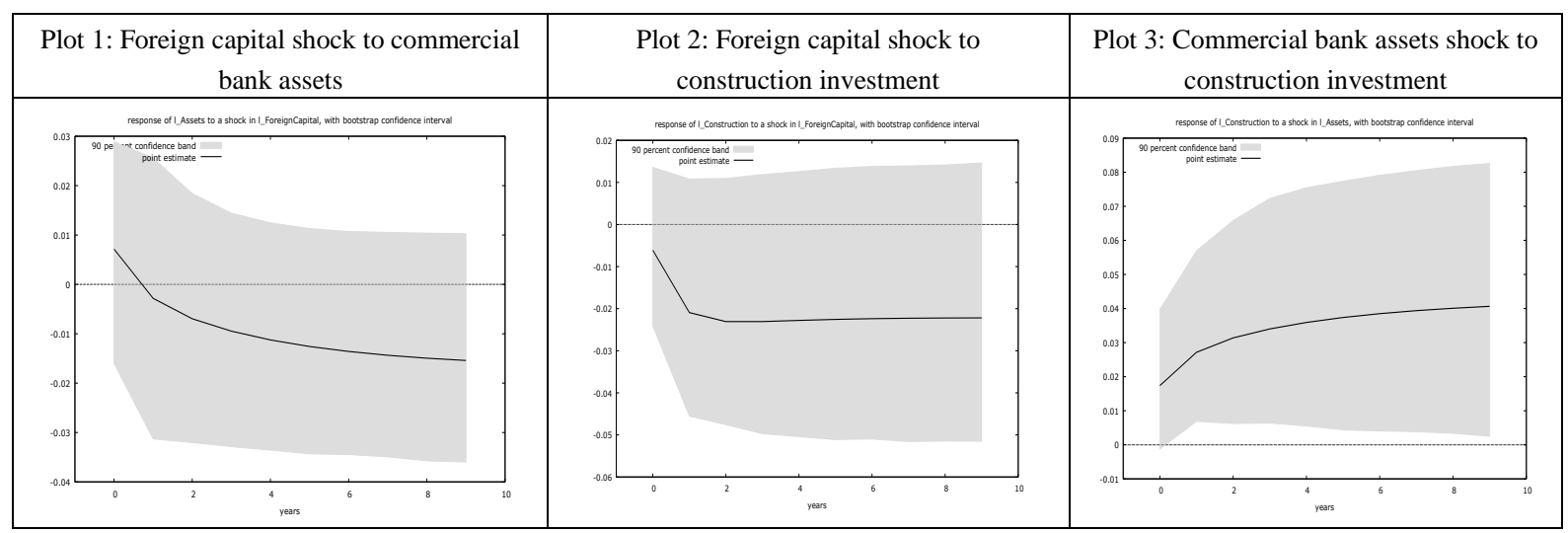

Figure 8. IRFs in the foreign capital inflows, commercial bank assets, construction investment VAR

Note. The solid lines trace the impulse responses while the area between the two dotted lines the $90 \%$ bootstrap confidence bands. These IRF are from VAR (1). The VAR lag length is selected by BIC.

Finally, we have repeated this Exercise by substituting foreign capital with remittances to assess what kind of investment the latter were addressed to. The findings of this Exercise are that remittances show a direct positive effect on both types of investment. These effects are permanent and significant (plots 1-2, Figures 9 and 10). In the case of investment in construction there is also an indirect effect through the banking system in the long run (plot 3 in Figure 10).

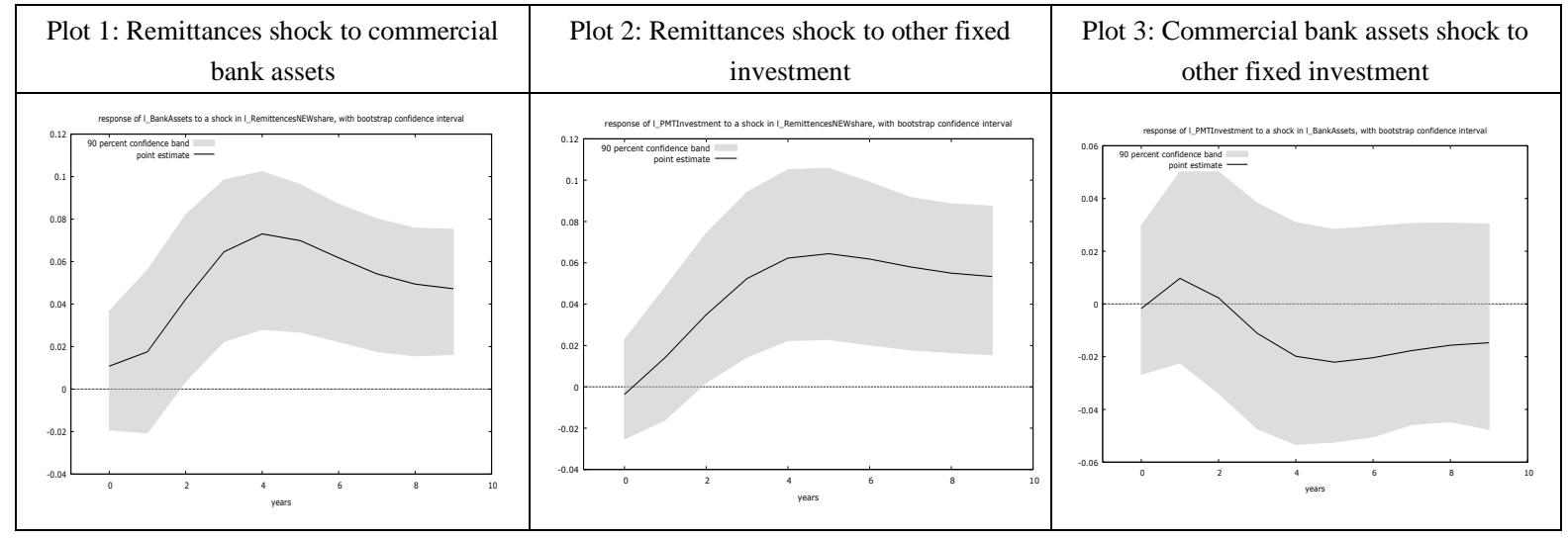

Figure 9. IRFs in the remittances, commercial bank assets, PMT investment VAR

Note. The solid lines trace the impulse responses while the area between the two dotted lines the $90 \%$ bootstrap confidence bands. These IRF are from VAR (2). The VAR lag length is selected by BIC. 


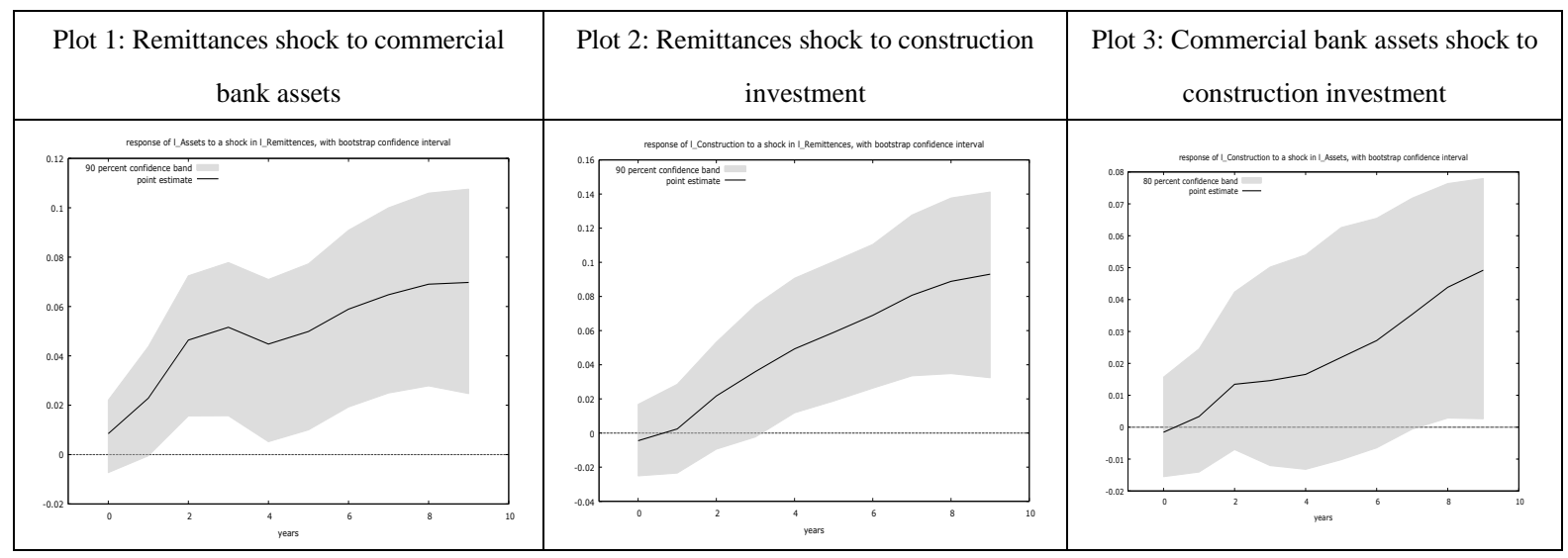

Figure 10. IRFs in the remittances, commercial bank assets, construction investment

Note. The solid lines trace the impulse responses while the area between the two dotted lines the $90 \%$ bootstrap confidence bands. These IRF are from VAR (4). The VAR lag length is selected by BIC

Overall, our econometric analysis stresses the key role of national saving's mobilization by domestic banks and of remittances - in this case both directly and through domestic banks' intermediation - in funding all types of investment in Italy. This was the case for both such industrial investment (typically a long-term investment) and investment in construction. Conversely, our result seems the case for role of foreign capital, also for investment in construction. However, foreign capital inflows might have been tied specifically to the most finance-driven investment such as big public work projects (including urban renewal) whereas small-scale private housing relied much more on domestic saving and remittances. As available data do not disaggregate between these two types of investment in constructions, they might have failed to capture the possible role of foreign capital in funding the former.

\section{Conclusions}

This paper analyses the relationship between various sources of financing - foreign capital, domestic savings, and remittances - and economic development in Italy from political unification in 1861 to World War I. To this aim, it uses IRF from a Cholesky identification scheme of a VAR model. It also relies on an original dataset that combines the most recent series of several financial and economic aggregates.

Because of the features of its economy at that time, Italy represents a good case study for the understanding of the process of economic development of those late coming countries which in the decades up to World War I were engaging in a process of industrialisation in the attempt to move from the periphery to the core of the global economy.

Existing literature has investigated the link between financial intermediation and economic development in these countries by focussing on one specific channel, being it international investment, domestic credit intermediation, or remittances. The main novelty of this paper, instead, consists in considering all these aspects together.

What emerges from this paper is that investment in Italy was fueled by a plurality of sources of funding, in contrast with what was commonly held in the literature. The general implication of our finding is that Italy at that time was probably a less backward country than commonly believed. Italy was able to build financial institutions capable of mobilizing and channeling non-negligible amounts of domestic savings that played a key role in financing investment.

A second result is the significant impact of remittances in funding investment over the period investigated. This result is original and stresses a point which was largely neglected by the common wisdom that views remittances as serving principally to adjust the balance of payments, prompt the diffusion of financial services, and increase consumption of Italian families.

Our evidence is instead weaker for foreign capital. Its effect seems negligible and never statistically significant for all kinds of investment. However, foreign capital inflows might have been tied specifically to the most finance-driven investment such as big public work projects and urban renewal plans in the major cities, whereas small-scale private housing relied much more on domestic saving and remittances. As available data do not disaggregate between these two types of investment in constructions, they might have failed to capture the possible role of foreign capital in funding the former. 


\section{References}

Baffigi, A. (2011). Italian national accounts, 1861-1911. Quaderni di Storia Economica. Economic History Working Papers No. 18, Banca d'Italia, Rome. https://doi.org/10.2139/ssrn.2239014

$\begin{array}{llllll}\text { Baffigi, } & \text { A. } & \text { (2017). } & N A & 150 . & \text { Rertrieved }\end{array}$ http://www.bancaditalia.it/statistiche/tematiche/stat-storiche/stat-storiche-economia/index.html

Balletta, F. (1976). Le rimesse degli emigranti italiani e la bilancia dei pagamenti internazionali 1861-1975. ESI, Naples.

Battilani, P. (1995). Il ruolo della strategia finanziaria nella performance dell'industria cotoniera italiana nel periodo fra le due guerre. Rivista di Storia Economica, 12, 57-89.

Borio, C., James, H., \& Song, S. H. (2014). The international monetary and financial system: a capital account historical perspective. BIS Working Papers No. 457. https://doi.org/10.24149/gwp204

Bosworth, B. P., Collins, S. M., \& Reinhart, C. M. (1999). Capital flows to developing economies: implications for saving and investment. Brookings Papers on Economic Activity, 1, 143-180. https://doi.org/10.2307/2534664

Broner, F., Didier, T., Erce, A.,\& Schmukler, S. (2013). Gross capital flows: Dynamics and crises. Journal of Monetary Economics, 60, 113-133. https://doi.org/10.1016/j.jmoneco.2012.12.004

Burhop, C. (2006). Did banks cause the German industrialisation? Explorations in Economic History, $43,39-63$. https://doi.org/10.1016/j.eeh.2005.04.005

Cameron, R. E. (1967). Banking in the Early Stages of Industrialization: A Study in Comparative Economic History. Oxford: Oxford University Press.

Carnevali, F. (2005). Europe's Advantage: Banks and Small Firms in Britain, France, Germany, and Italy since 1918. Oxford: Oxford University Press. https://doi.org/10.1093/0199257396.001.0001

Coletti, F. (1911). Dell'emigrazione italiana. Hoepli, Milan.

Confalonieri, A. (1974-76). Banca ed industria in Italia 1894-1906 (Vol. 3). Banca Commerciale Italiana, Milan.

Confalonieri, A. (1982). Banca e industria in Italia dalla crisi del 1907 all'agosto 1914 (Vol. 2). Banca Commerciale Italiana, Milan.

Conti, G. (2007). Creare il credito e arginare i rischi. Il sistema finanziario tra nobiltà e miserie del capitalismo italiano. Il Mulino, Bologna.

De Bonis, R., \& Silvestrini, A. (2014). The Italian financial cycle: 1861-2011. Cliometrica, 8, $301-334$. https://doi.org/10.1007/s11698-013-0103-5

De Bonis, R., Farabullini, F., Rocchelli, M., \& Salvio, A. (2013). Nuove serie storiche sull'attività delle banche e altre istituzioni finanziarie dal 1861 al 2011: Che cosa ci dicono? Quaderni di Storia Economica, Economic History Working Papers No. 26, Banca d'Italia, Rome.

De Clementi, A. (1994). Rimesse e mercati. Parolechiave, 6, 89-104.

De Mattia, R. (1967). I bilanci degli istituti di emissione italiani 1845-1936 (Vol. I, tomi I and II). Staderini, Rome.

De Rosa, L. (2000). Le rimesse degli emigrati e lo sviluppo economico dell'Italia (1861-1914). Nuova rivista Storica, 84(3), 563-574.

De Rosa, L. (2011). Sull'emigrazione italiana. Rubbettino, Soveria Mannelli.

Della Torre, G., Coccìa, M., De Leonardis, V., \& Schisani, M. C. (2008). Growth of the Italian Financial System after Political Unification, 1861-1914: Financial Deepening and/or Statistical and Methodological Biases? Rivista di Storia Economica, 24(2), 135-174.

Diekmann, K., \& Westermann, F. (2012). Financial development and sectoral output growth in nineteenth-century Germany. Financial History Review, 19, 149-174. https://doi.org/10.1017/S0968565012000066

Doornik, J. A. (1998). Approximations to the asymptotic distribution of cointegration tests. Journal of Economic Surveys, 12, 573-593. https://doi.org/10.1111/1467-6419.00068

Douki, C. (2001). Les forms de l'intégration spatiale. Le territoire économique d'une région d'émigration: 
campagnes et montagnes lucquoises, du milieu du XIXe siècle à 1914. Revue d'Histoire Moderne et Contemporaine, 48, 192-246. https://doi.org/10.3917/rhmc.482.0192

Esteves, R., \& Khoudour-Castéras, D. (2009). A Fantastic Rain of Gold: European Migrants' Remittances and Balance of Payments Adjustment During the Gold Standard period. The Journal of Economic History, 69, 951-985. https://doi.org/10.1017/S002205070900134X

Esteves, R., \& Khoudour-Castéras, D. (2011). Remittances, capital flows and financial development during the mass migration period, 1870-1913. European Review of Economic History, 15, 443-474. https://doi.org/10.1017/S1361491611000037

Faina, E. (1911). Relazione finale all'inchiesta parlamentare sulle condizioni dei contadini nelle province meridionali e nella Sicilia. Berbero, Rome.

Fauri, F. (2015). Storia economica delle migrazioni italiane. Il Mulino, Bologna.

Federico, G., \& Tena-Junguito, A. (2016). World trade, 1800-1938: A new data set. EHES Working Paper No. 93.

Federico, G., Natoli, S., Tattara, G., \& Vasta, M. (2011). Il commercio estero italiano. 1862-1950. Laterza, Rome and Bari.

Fenoaltea, S. (1988). International resource flows and construction movements in the Atlantic economy: The Kuznets cycle in Italy, 1861-1913. The Journal of Economic History, 48, 605-637. https://doi.org/10.1017/S0022050700005854

Fenoaltea, S. (2003). Notes on the rate of industrial growth in Italy, 1861-1913. The Journal of Economic History, 63, 695-735. https://doi.org/10.1017/S0022050703541961

Fenoaltea, S. (2005). The growth of the Italian economy, 1861-1913: Preliminary second-generation estimates. European Review of Economic History, 9, 273-312. https://doi.org/10.1017/S136149160500153X

Fenoaltea, S. (2011). The reinterpretation of Italian economic history: From unification to the Great War. Cambridge: Cambridge University Press. https://doi.org/10.1017/CBO9780511730351

Fenoaltea, S. (2017). The Fruits of Disaggregation: the Engineering Industry, Tariff Protection, and the Industrial Investment Cycle in Italy, 1861-1913. Banca d'Italia - Economic History Working Papers No. 41. https://doi.org/10.2139/ssrn.3082189

Fenoaltea. (2018). The Growth of the Italian Economy, 1861-1913: Revised Second-Generation Expenditure-Side Estimates. MPRA Paper No. 88016.

Ferrandino, V. (2011). Banche ed emigranti in Molise. Franco Angeli, Milan.

Fohlin, C. (1998). Fiduciari and firm liquidity constraint: the Italian experience with German-style universal banking. Explorations in Economic History, 35, 83-107. https://doi.org/10.1006/exeh.1997.0690

Fohlin, C. (1999). Capital mobilisation and utilisation in latecomer economies: Germany and Italy compared' European Review of Economic History, 3, 139-174. https://doi.org/10.1017/S1361491699000088

Gabaccia, D. R. (2000). Italy's Many Diasporas. Routledge, London and New York.

Gerschenkron, A. (1962). Economic Backwardness in Historical Perspective. Cambridge, MA: Cambridge University Press.

Granger, C. W. J. (1969). Investigating causal relations by econometric models: cross spectral methods. Econometrica, 37, 424-438. https://doi.org/10.2307/1912791

Gurley, J. G., \& Shaw, E. S. (1955). Financial aspects of economic development. American Economic Review, 45, 515-538.

Hertner, P. (1984). Il capitale tedesco in Italia dall'Unità alla prima guerra mondiale: Banche miste e sviluppo economico italiano Il Mulino, Bologna.

Incerpi, A. (2018). Of Finance and Trade: Three Essays on the Italian Economic History. Ph.D. Thesis, University of Siena, Department of Economics and Statistics.

Incerpi, A. (2019). Balancing the current account: remittances and tourism in Italy, 1861-1914. Rivista di Storia Economica, forthcoming.

Istat. (1957). Indagine statistica sullo sviluppo del reddito nazionale dell'Italia dal 1861 al 1956. Annali di Statistica, Serie VIII, 9. 
Jones, M. T., \& Obstfeld, M. (2004). Saving, investment, and gold: A reassessment of historical current account data. In G. A. Calvo, R. Dornbusch, \& M. Obstfeld (Eds.), Capital Mobility, and Trade: Essays in Honor of Robert A. Mundell (pp. 303-360). MIT Press, Cambridge, MA.

King, R. G., \& Levine, R. (1993). Finance and growth: Schumpeter might be right. Quarterly Journal of Economics, 108, 717-737. https://doi.org/10.2307/2118406

Lane, P. R., \& McQuade, P. (2014). Domestic credit growth and international capital flows. The Scandinavian Journal of Economics, 116, 218-252. https://doi.org/10.1111/sjoe.12038

Lehmann-Hasemeyer, S. H., \& Wahl, F. (2017). Savings banks and the industrial revolution in Prussia: Supporting regional development with public financial institutions. Hohenheim Discussion Papers in Business, Economics and Social Sciences No. 18.

Levine, R. (1997). Financial development and economic growth: Views and agenda. Journal of Economic Literature, 35, 688-726.

MacKinnon, J. G. (1996). Numerical distribution functions for unit root and cointegration tests. Journal of Applied

601-618. https://doi.org/10.1002/(SICI)1099-1255(199611)11:6<601::AID-JAE417>3.0.CO;2-T

Pesaran, M. H., \& Shin, Y. (1998). Generalized Impulse Response Analysis in Linear Multivariate Models. Economics Letters, 58, 17-29. https://doi.org/10.1016/S0165-1765(97)00214-0

Rey, G. M. (ed.) (1992). I conti economici dell'Italia. 2. Una stima del valore aggiunto per il 1911. Laterza, Rome-Bari.

Rey, G. M. (ed.) (2000). I conti economici dell'Italia. 3. Il valore aggiunto per gli anni 1891, 1938, 1951. Laterza, Rome-Bari.

Rey, G.M. (ed.) (2002). I conti economici dell'Italia. 3. Il conto risorse e impieghi (1891, 1911, 1938, 1951). Laterza, Rome-Bari.

Rinaldi, A., \& Spadavecchia, A. (2019). The banking-industry relationship in Italy: Large national banks and small local banks compared (1913-1936). Business History. https://doi.org/10.1080/00076791.2019.1598975

Rousseau, P. L., \& Sylla, R. (2005). Emerging financial markets and early US growth. Explorations in Economic History, 42, 1-26. https://doi.org/10.1016/j.eeh.2004.03.004

Rousseau, P. L., \& Wachtel, P. (1998). Financial intermediation and economic performance: Historical evidence from five industrialised countries. Journal of Money, Credit, and Banking, 30, 657-678. https://doi.org/10.2307/2601123

Schularick, M., \& Steger, T. M. (2010). Financial integration, investment, and economic growth: Evidence from two eras of financial globalization. The Review of Economics and Statistics, 92, 756-768. https://doi.org/10.1162/REST_a_00027

Sims, C. A., Stock, J. H., \& Watson, M. W. (1990). Inference in linear time series models with unit roots. Econometrica, 58, 113-144. https://doi.org/10.2307/2938337

Sori, E. (1987). L'emigrazione italiana dall'Unità alla seconda guerra mondiale. Il Mulino, Bologna.

Stock, J. H., \& Watson, M. W. (2001). Vector Autoregressions. Journal of Economic Perspectives, 15(4), 101-115. https://doi.org/10.1257/jep.15.4.101

Stringher, B. (1912). Su la bilancia dei pagamenti fra l'Italia e l'estero. Riforma Sociale, 23, 49-83.

Tornell, A., \& Schneider, M. (2004). Balance sheet effects, bailout guarantees and financial crises. Review of Economic Studies, 71, 883-913. https://doi.org/10.1111/j.1467-937X.2004.00308.x

Vasta, M., Drago, C., Ricciuti, R., \& Rinaldi, A. (2017). Reassessing the bank-industry relationship in Italy, 1913-1936: A counterfactual analysis. Cliometrica, 11(2), 183-216. https://doi.org/10.1007/s11698-016-0142-9

Warglien, M. (1987). Investimento industrial e instabilità finanziaria in Italia, 1878-1913. Rivista di Storia Economica, n.s., 4, 384-439. 


\section{Notes}

Note 1. Partial exceptions are, among others, Bosworth et al. (1999) and Lane and McQuade (2014).

Note 2. This result is confirmed by Battilani (1995) who analyzed the balance-sheets of a sample of Italian cotton firms.

Note 3. We focus on commercial banks - the banks that were joint-stock companies according to Italian legislation - because they might have had links to international investors, whereas the other credit institutions (i.e., savings and cooperative banks) were supposed to collect mainly if not exclusively domestic saving.

Note 4. We thank Alberto Baffigi of the Bank of Italy for his clarification on this point.

Note 5. For a review on VAR models, Stock and Watson (2001).

Note 6. See Sims, Stock and Watson (1990).

Note 7. The results are available on request.

Note 8 . The results are available on request.

\section{Appendix A}

\section{Integration Analysis}

This section shows the integration analysis performed on the variables involved in the different specifications of the built VAR models. The analysis carried out through the use of ADF (Augmented Dickey Fueller) tests. As mentioned previously, this analysis shows that the variables of interest are all integrated first-order, i.e. I (1): in other words, the levels of the variables analyzed are not stationary, while the raw differences are stationary. Below is a summary table of the results obtained, followed by the single unit root tests carried out on the different series.

Table A1. Integration analysis: results from ADF (OLS) tests

\begin{tabular}{|c|c|c|c|c|c|}
\hline \multirow{3}{*}{ Variables } & \multicolumn{2}{|r|}{ Levels } & & \multicolumn{2}{|c|}{$\mathbf{1}^{\text {st }}$ Differences } \\
\hline & ADF (p) & ADF (p) & p-lags & $\operatorname{ADF}(\mathbf{p})$ & p-lags \\
\hline & With constant & With constant and trend & & With constant & \\
\hline \multirow[t]{2}{*}{ Foreign Capital Inflows } & -1.70 & -3.10 & 0 & -11.07 & 0 \\
\hline & $(0.43)$ & $(0.12)$ & & $(0.00)$ & \\
\hline \multirow[t]{2}{*}{ Remittances } & -0.87 & -2.45 & 2 & -6.21 & 1 \\
\hline & $(0.79)$ & $(0.14)$ & & $(0.00)$ & \\
\hline \multirow[t]{2}{*}{ Commercial Banks Assets } & -1.85 & -1.99 & $1-1$ & -4.15 & 0 \\
\hline & $(0.35)$ & $(0.60)$ & & $(0.00)$ & \\
\hline \multirow[t]{2}{*}{ Total Investment } & -2.91 & -3.58 & 1 & -5.26 & 0 \\
\hline & $(0.04)$ & $(0.03)$ & & $(0.00)$ & \\
\hline \multirow[t]{2}{*}{ OFI Investment } & -1.94 & -2.55 & 2 & -4.71 & 0 \\
\hline & $(0.30)$ & $(0.30)$ & & $(0.00)$ & \\
\hline \multirow[t]{2}{*}{ Constructions Investment } & -2.42 & -2.84 & 1 & -3.74 & 0 \\
\hline & $(0.13)$ & $(0.18)$ & & $(0.00)$ & \\
\hline
\end{tabular}

Note. The ADF (OLS) tests are calculated for levels and first difference of the variables. The lag length is selected by BIC. ADF with a constant: $\Delta \mathrm{Y}_{\mathrm{t}}=\alpha+\delta \mathrm{Y}_{\mathrm{t}-1}+\ldots+\mathrm{u}_{\mathrm{t}}$. ADF with constant and trend: $\Delta \mathrm{Y}_{\mathrm{t}}=\alpha+\beta$ trend $+\delta \mathrm{Y}_{\mathrm{t}-1}+\ldots+\mathrm{u}_{\mathrm{t}}$. Asymptotic $\mathrm{p}$-values in parenthesis $($.) are from McKinnon (1996). All the variables are ratio to GDP. All ratios are in logs.

\section{Appendix B}

\section{A.2. Co-integration Analysis}

This section shows the co-integration analysis of the variables jointly involved in the different specifications of the estimated VAR models. For this purpose, we use the Johansen analysis procedure (Trace and Max-Eigenvalue statistics). Overall, there is substantial evidence on the existence of co-integration between the series as reported in the table and, subsequently, from the outputs of the individual co-integration analyzes carried out. 
Table A2. Cointegration analysis: results from Johansen estimation

\begin{tabular}{|c|c|c|c|c|c|}
\hline \multirow{3}{*}{$\begin{array}{l}\text { VAR(lags): Variables } \\
\text { VAR(1): Foreign Capital Inflows, Commercial } \\
\text { Banks Assets, Total Investment }\end{array}$} & \multicolumn{3}{|c|}{ Trace test [p-values] } & \multicolumn{2}{|c|}{ Max-eigenvalues [p-values] } \\
\hline & $\mathrm{R}=0$ & \multicolumn{2}{|l|}{$45.446[0.0003]$} & $\mathrm{R}=0$ & $38.903[0.0000]$ \\
\hline & $\mathrm{R}<=1$ & \multicolumn{2}{|l|}{$6.5430[0.6363] *$} & $\mathrm{R}<=1$ & $5.8359[0.6396]^{*}$ \\
\hline & $\mathrm{R}<=2$ & \multicolumn{2}{|l|}{$0.70708[0.4004]$} & $\mathrm{R}<=2$ & $0.70708[0.4004]$ \\
\hline \multirow{3}{*}{$\begin{array}{l}\text { VAR(1): Remittances, Commercial Bank Assets, } \\
\text { Total Investment }\end{array}$} & $\mathrm{R}=0$ & \multicolumn{2}{|l|}{$27.104[0.1013]$} & $\mathrm{R}=0$ & $20.213[0.0661]$ \\
\hline & $\mathrm{R}<=1$ & $6.8911[0.5963]$ & \# & $\mathrm{R}<=1$ & $5.8078[0.6431] \#$ \\
\hline & $\mathrm{R}<=2$ & \multicolumn{2}{|l|}{$1.0832[0.2980]$} & $\mathrm{R}<=2$ & $1.0832[0.2980]$ \\
\hline \multirow{3}{*}{$\begin{array}{l}\text { VAR(1):Foreign Capital Inflows, Commercial } \\
\text { Bank Assets, OFI Investment }\end{array}$} & $\mathrm{R}=0$ & \multicolumn{2}{|l|}{$35.617[0.0088]$} & $\mathrm{R}=0$ & $31.088[0.0009]$ \\
\hline & $\mathrm{R}<=1$ & \multicolumn{2}{|l|}{$4.5291[0.8524]^{*}$} & $\mathrm{R}<=1$ & $2.6070[0.9594]^{*}$ \\
\hline & $\mathrm{R}<=2$ & \multicolumn{2}{|l|}{$1.9222[0.1656]$} & $\mathrm{R}<=2$ & $1.9222[0.1656]$ \\
\hline \multirow{3}{*}{$\begin{array}{l}\operatorname{VAR}(1) \text { : Foreign Capital Inflows, Commercial } \\
\text { Bank Assets, Constructions Investment }\end{array}$} & $\mathrm{R}=0$ & \multicolumn{2}{|l|}{$32.013[0.0267]$} & $\mathrm{R}=0$ & $28.244[0.0031]$ \\
\hline & $\mathrm{R}<=1$ & \multicolumn{2}{|l|}{$3.7692[0.9143] *$} & $\mathrm{R}<=1$ & $3.7111[0.8803]^{*}$ \\
\hline & $\mathrm{R}<=2$ & \multicolumn{2}{|l|}{$0.058105[0.8095]$} & $\mathrm{R}<=2$ & $0.058105[0.8095]$ \\
\hline \multirow{3}{*}{$\begin{array}{l}\text { VAR(2): Remittances, Commercial Bank Assets, } \\
\text { OFI Investment }\end{array}$} & $\mathrm{R}=0$ & \multicolumn{2}{|l|}{$57.844[0.0000]$} & $\mathrm{R}=0$ & $47.460[0.0000]$ \\
\hline & $\mathrm{R}<=1$ & $10.384[0.2568]$ & * & $\mathrm{R}<=1$ & $6.3395[0.5772]^{*}$ \\
\hline & $\mathrm{R}<=2$ & \multicolumn{2}{|l|}{$4.0448[0.0443]$} & $\mathrm{R}<=2$ & $4.0448[0.0443]$ \\
\hline \multirow{3}{*}{$\begin{array}{l}\text { VAR(4): Remittances, Commercial Bank Assets, } \\
\text { Constructions Investment }\end{array}$} & $\mathrm{R}=0$ & \multicolumn{2}{|l|}{$42,391[0,0009]$} & $\mathrm{R}=0$ & $27,721[0,0038]$ \\
\hline & $\mathrm{R}<=1$ & $14,669[0,0651]$ & * & $\mathrm{R}<=1$ & $10,980[0,1573]^{*}$ \\
\hline & $\mathrm{R}<=2$ & \multicolumn{2}{|l|}{$3,6896[0,0548]$} & $\mathrm{R}<=2$ & $3,6896[0,0548]$ \\
\hline
\end{tabular}

Note. The Johansen estimation is from a system with an unrestricted constant corresponding to deterministic cointegration: the variables are cointegrated sharing common deterministic and stochastic trends. The VAR lag length is selected by BIC. P-values for the cointegrating rank in [.] are computed by Doornik (1998).* indicates significance level at $5 \%$ while \# at the $10 \%$.

\section{Copyrights}

Copyright for this article is retained by the author(s), with first publication rights granted to the journal.

This is an open-access article distributed under the terms and conditions of the Creative Commons Attribution license (http://creativecommons.org/licenses/by/4.0/). 